\title{
Coping Strategies Used By Students with Disabilities in Managing Social and Higher Educational Experiences
}

\author{
Dr. Nageswara Rao Ambati ${ }^{1}$
}

\section{ABSTRACT:}

This study attempts to understand social and educational experiences of students with disabilities in institutions of higher education and is exploratory in nature. To understand the educational experiences of these students, it is not enough to know only the availability of services and resources. It is also necessary to understand the students personally, and the circumstances in which they live. To answer the research questions posed in this study, the researcher has used mixed methods and three universities were selected through purposive sampling in so as to gain maximum diverse variation. For this study, in-depth interviews were conducted with hundred students with disabilities in selected universities in Andhra Pradesh, India. In this study, quantitative and qualitative data analyses were used and in most cases quotes of real text for each theme were maintained and used extensively. The findings of the study show the students were very categorical about their special needs in order to achieve their goals. A greater understanding has been gained regarding coping strategies adopted by them to manage their higher education needs. Based on findings of the study the researcher has brought out the factors which influence the creation of an inclusive environment in institutions of higher education.

Keywords: Students with disabilities, Higher education, coping strategies, Challenges

People with disabilities form a significant part of the world population. The exact numbers are hard to discern due to suspected underreporting and differences in the definition of disability between countries, and cultures (Yeo and Moore, 2003). It is estimated that approximately 650 million people of global population, or ten per cent of the total population, live with disability. The experience of people with disability varies depending on their personal circumstances, availability of resources and other external factors. Similarly, students with disabilities represent an emerging population in higher education institutions, whose perceptions and experiences of higher education are ultimately shaped by their socio-cultural experiences, the existing of environment, and the availability of specific facilities, required by them. Despite notable progress in legislations and policies for these students in higher education institutions, many of them still face various challenges in completing their studies successfully. An attempt has been made here to present some aspects of their academic life.

${ }^{1}$ Assistant Professor of Sociology, Gujarat National Law University, Attalika Avenue, Knowledge Corridor, Koba, Gandhinagar, India 


\section{Coping Strategies Used By Students with Disabilities in Managing Social and Higher Educational Experiences}

Achieving success in higher education institutions for these students, not only require an ability to manage academic challenges but also challenges, faced due to their impairments. To manage the academic and social demands of higher education at the university level, students need to understand their disabilities, develop effective coping strategies to manage their condition, accept their strengths and limitations, have awareness about policies and support available, and have access to, and seek, support services, when needed on and off campus. Unfortunately it was also found that there is a dearth of research studies in the Indian context. This study aims to explore factors or barriers which affect the social and educational experience of students with disabilities in higher education institutions in Andhra Pradesh, India.

\section{BACKGROUND OF THE STUDY}

Since education is viewed as an instrument of social change, social mobility, equality and integration, the political elite, social reformers and intellectuals do think and advocate that, along with other marginal sections of the society, persons with disabilities need to be given access to education, even if it means giving special privileges (Chanana, 1993). In order to achieve this aim, the Government of India has enacted three legislations for persons with disabilities. Among them, Persons with Disabilities (Equal Opportunities, Protection of Rights and Full Participation) Act, 1995 is an important legislation. It is also meant to provide education, employment, creation of barrier free environment, social security, etc. (See Disability India Network). The Act also states that free and compulsory education has to be provided to all children with disabilities up to the minimum age of 18 years.

All these policies brought about significant changes to provide more educational opportunities to children with disabilities at regular schools, as well as in the enrolment of students with disabilities in higher education institutions. More number of students with disabilities now chooses to attend institutions of higher education due to accessibility laws, legislation support, disability advocacy groups, and developments in technology (Hirschorn, 1992). Consequently, policy and provisions for students with disabilities have taken place within different educational structures and systems. For instance, in India, the Action Plan for Inclusive Education of Children and Youth with Disabilities (IECYD), 2005 has put emphasis on higher education for students with disabilities.

Further, universities have begun to extend the provision of support services to ensure their active participation and success. The UGC, on its part, is committed to implement higher education related guidelines and schemes as per the provisions of the PWD Act and the directions issued by the Government of India from time to time (See Extracts from the XI Plan UGC Guidelines on Grants to Universities). Thus, the universities and colleges are encouraged to procure such devices including computers with screen reading soft-wares, low-vision aids, scanners, readers and scribers for visually challenged students, mobility devices etc. With all these policies and provisional support services of the government of India, the University Grants Commission aims at providing equal educational opportunities to student with disabilities and ensuring their full 


\section{Coping Strategies Used By Students with Disabilities in Managing Social and Higher Educational Experiences}

participation in higher education institutions. Although various steps have been taken in order to improve the higher educational opportunities for students with disabilities, there are very few explicit signs of progress. According to University Grants Commission (UGC), 6 per cent of the youth population is enrolled in Indian universities and colleges. Based on the most conservative estimates for the disabled youth population in India, approximately at least 3,160,000 disabled youth should be in the Indian universities and colleges. However, just 1.2 per cent of the 3.6 lakh disabled youth are in the universities and colleges. It can be concluded that higher educational system in India is not accessible to 98.8 per cent of its disabled youth. Similarly, a survey conducted by National Centre for Promotion of Employment for Disabled People (NCPEDP, 2005) shows that only 0.1 per cent (male 0.07 per cent, female 0.03 per cent) of the total number of students in 52 universities were those with disabilities. Although 3 per cent seats are reserved for the students with disabilities; this indicates that these students are not able to reach the higher levels of education. This study concludes that most of the institutions obviously did not understand the issue of access and were under the impression that all the places were accessible to all present and future students with disabilities. But there is a dearth of research focused on this area specifically in the Indian context. Therefore, the current study aims to explore the educational experiences of students with disabilities in higher education institutions in Andhra Pradesh.

\section{REVIEW OF LITERATURE}

In general, personal factors are those that are individual to each student and may include selfdetermination skills, self-efficacy, and self-esteem and the way they (SWDs) experience symptoms of a disability. Self-determination is an important construct for the general population but it is especially important for the students with disabilities who have enrolled in higher education institutions. For Ward (1988), the word self-determination includes actions such as setting goals, identifying steps necessary to achieve the goals, and overcoming various barriers to goal attainment. In additions, the definition also includes key components such as choicemaking, decision-making, problem-solving, and goal- setting and attainment. These kinds of skills must be taught to these students who are enrolled in higher education institutions for the improvement of their living conditions.

Similarly, a qualitative study was conducted by Barron (2001) show that those who had more autonomy had more social skills and exposure to the society than those who did not have autonomy. The author points out that due to lack of social skills and self-determination in those students, opportunities to make and fulfill the choices of their life are denied. In addition to disclosing about the special requirements, one also needs to understand the factors which might improve the educational and social experiences of students with disabilities in higher education institutions (Jacklin, Robinson, and Harris, 2007). Similarly, self-advocacy and appropriate disclosure are ultimately responsible for management of higher education successfully for students with disability. To understand the role of self-advocacy and appropriate disclosure in 


\section{Coping Strategies Used By Students with Disabilities in Managing Social and Higher Educational Experiences}

coping with experiences of students with disabilities, including physical barriers in the environment, and support barriers, a study was contributed by Adrianne (2006). The author notes that, if accommodation was needed within a college setting, a student was required to disclose the disability and related needs, but multiple dilemmas arose for the students as when to disclose, how to disclose, how much to disclose and whom to disclose. The author found that disability of students increased the perception that they were devalued and stigmatised, and sometimes they felt concerned about negative results of disclosing their disability. The researcher has suggested that, in order to resolve this problem, higher education institutions need to encourage the students with disabilities to disclose their disability.

Similarly, Nunkoosing and John (1997) study revealed that friendship was facilitated by mutuality and acceptance, whereas poverty, limited transport and absence of physical and emotional support prevented the development of friendship and lead to the experience of loneliness. It also found that participants managed their experiences of rejection and loneliness through the development of various coping strategies such as self-advocacy skills and positive self-image. Further, it is important $t$ to understand the impact of social support, relations, and friendships of these students on their educational success, failures and stress in educational institutions and students' perceived social support, stress and sense of coherence. The study by Heiman's (2006) reveals that the perception of lower social support of the learning disability group highlights the importance of the social setting in supporting and helping students with learning disability to successfully adjust to higher education.

The studies have elaborated on the importance of social factors and their impact on educational experiences of students with disabilities in higher education institutions. The activities or interactions between a student and the campus environment facilitate developmental changes that imply either successful or unsuccessful integration, and adaptation and adjustment to the social and academic aspects of college life. The review of the studies such as Nunkoosing and John (1997), Hoy et al, (1997), Cosden and McNamara (1997) stresses the importance of social support, social relations, and friendships for a successful adjustment to higher education. It is surprising to note that many of the studies in this section focused on learning disability. The researcher could not find many studies on social experiences of students with disabilities in higher education institutions. Further, it is interesting to note that none of the studies explored how gender plays an important role in maintaining social and friendly relation, and how they are coping with their day-to-day activities. Similarly, much research needs to be done on family support received by students' with disabilities and its impact on their education.

\section{RESEARCH QUESTIONS}

1) What are the factors which promote or hinder the process of social and educational advancement of students with disabilities at higher educational levels? 


\section{Coping Strategies Used By Students with Disabilities in Managing Social and Higher Educational Experiences}

2) What kind of strategies are the students using to cope their experiences in higher education institutions?

\section{RESEARCH METHODOLOGY}

The present study is exploratory in nature. To answer the research questions posed in this study, the researcher used a mixed method approach which is a procedure for collecting, analysing and mixing or integrating both quantitative and qualitative data at different stages of the research process within a single study. The study conducted in the State of Andhra Pradesh which has the higher number of academic institutions in India in terms of higher education and also enrolment. At present, it has a total number of 35 universities; of which three of them are central universities and 27 of them are state universities, and 5 are deemed universities.

For this study, the researcher has collected data from three universities in different parts of Andhra Pradesh. These three universities have different characteristics such as

- One is a Central and the other two are State universities. The Central and one of the State universities (a) have both a disability cell as well as a coordinator to look after the needs of students with disabilities in their respective universities whereas the second State University (b) has neither a disability cell nor a disability coordinator.

- Finally, the Central University has higher total enrolment and thus has greater number of students with disabilities, as compared to both the State universities.

In the second phase, after selecting the universities, the researcher interviewed all students with disabilities from each university by using snowball sampling. It was very difficult to get details about students with disabilities from the university management or disability office due to lack of data base regarding the number of students with disabilities enrolled. That is why the researcher used snowball sampling. Students' were interviewed with the help of semi-structured in-depth interview schedules. In all 100 students were included in this study (48 from Central University and 26 each from the State Universities ( $a$ and b). For this study, quantitative and qualitative data analyses were used and in most cases quotes of real text for each theme were maintained and used extensively.

\section{RESULTS AND DISCUSSION}

\section{Brief profile of the respondents:}

For the study data was collected from 100 students with disabilities (66 per cent of them were male and 34 were female students). Out of them 72 per cent of the respondents were orthopedically impaired and 28 per cent were visually impaired. Representation of orthopedically impaired students is nearly more than 2 times higher than that of visually impaired students. The 


\section{Coping Strategies Used By Students with Disabilities in Managing Social and Higher Educational Experiences}

researcher could not find students with other type of impairments during data collection time. The fact was that some of the students actually didn't want to disclose their disability. The researcher found that three students with hearing impairment (two from Central University and one from a State University (b)) did not disclose their nature of impairment at the time of admission. They wanted to be treated like any other student in the university. When the researcher asked them to be respondents in this study, they did not agree to do so and simply stated that didn't have any major problems related to their impairments at university.

\section{Motivation to Pursue Higher Education}

Students were asked questions regarding their motivation and interest to pursue higher education at the university level despite being students with disabilities and their previous diverse educational experiences. The researcher found that out of the many reasons reported by the respondents, there were significant commonalities that emerged. Many of the students in the current study had aspirations to build an independent life, by getting a proper job. Many students pursued higher education because they either saw it as an economic necessity to have better living conditions or a place to prove their self-worth. From the data gathered here, present employability conditions influenced their decision to go in for higher education. The following quotes illustrate the reasons for pursuing higher education at university level:

"I just wanted to have a better quality of life, but for that I need to have a good degree which would give me good job."

"If I do not have good qualifications it will not be possible to get anywhere in the present knowledge society."

"I want to become independent. I do not want to depend on others people's sympathy for my survival. I want to take care of my parents and fulfill their dreams."

"I decided to get a doctorate when I passed tenth standard with good results. I am interested in not only making a difference in this world, but also wanting to make this world a better place."

Some of the respondents stated that they did not want to go for work in clerical, or other fourth grade jobs. A few of them had already experienced bad working environment after completion of their degrees and realised that higher education would increases their chances for better employment opportunities and good working conditions.

\section{Friendships and Social Relationships with their Peer Group}

A person's life revolves around his/her network of social relationships which provide the person opportunities to develop valued social roles as friends and companions (Frith and Rapley, 1990). Yet, the overriding concerns of services for people with disabilities - access, autonomy and the development of independence. Disability organisations and other activists have been concerned with the rights of persons with disabilities than with friendships and relationships. In this study, 


\section{Coping Strategies Used By Students with Disabilities in Managing Social and Higher Educational Experiences}

the researcher made efforts in understanding social relations and friendships of students with disabilities which create interdependence among communities and mutual support for them.

For making new friends and developing new relations, students require the ability to share in a deeper level with others and should have a good intimacy with each other. In this study, respondents were able to make new friends. Sixty four per cent of them reported that they are able to make new friends and have become very close. They believed that their friends could provide good strength whenever they would need any kind of support. In contrast, 36 per cent of them find making and developing friendships as challenging, depending on the nature of their personality and disability. Social life and friendships for these students could be potentially very different from students without disabilities. As many of them were sensitive about others findings out about their disability and ridiculing them, sometimes these students were introvert and had difficulty making and maintaining friendships and other social relations. They expressed wide range of reasons affecting and making their new friendships and social life.

"I have good number of friends not only in my class as well as in hostel, but also on the entire campus. Especially, my roommates and friends are very understanding and supportive."

"I am used to go outside with my friends. They do not treat me as different from others. The fact is that I will not give them a chance to think that I am a person with a disability. We are used to go for shopping, cinemas and having dinner outside all together while returning."

"Here, I am able to make new friends who are very cooperative. Today I am able to study well just because of their cooperation and help. During exam times, they read for me."

"Deepika is my best and close friend. We are friends from childhood. Wherever we would be going out, we go together. Even though I have only a few friends, at no time do I feel lonely since I have my friend with me."

"I enjoyed most of my social life and spent time only with my friends. They are very supportive and cooperative."

The results reveal that the respondents shared many of the same concerns and priorities as the college students without disabilities. A study by Cosden and McNamara (1997) also indicates that students with disabilities do not have problems with their social skills or in their relationships. It is possible that students with disabilities who have stronger social relationships are more successful in education and are more likely to attend college. However, it is also possible that these results are associated with the students' opportunities to develop social supports through campus programmes. Further, in the current study, it was apparent from the students' comments that many friendships were based on mutuality and reciprocity. Respondents had the capacity to develop friendships where there are mutual exchanges concerning understanding their needs, emotional support and practical assistance. 


\section{Coping Strategies Used By Students with Disabilities in Managing Social and Higher Educational Experiences}

Despite the positive aspects of making friendships and relationships, thirty six per cent of the students found developing and maintaining friendships to be more challenging. Some of them did not feel comfortable while interacting with new people. They had more difficulty making friends while also dealing with manifestations of their disability and tended to be more isolated. Some students with visual impairments lacked time to spend with friends or to make new relationships. Because just focusing on the academic activities at the university was somewhat overwhelming. They had little time to be participants in student organisations, cultural activities, socialise in the student groups or attend several events at the university. They felt that they failed to get the overall university educational experience. Further, they believed that they need to put in more hard work to get good academic qualifications for good employment opportunities and also desire to be independent in their studies. The following statement is significant:

"Due to my visual impairment, I have to scan all material I get from my friends, teachers. If I want to be independent in my studies, I have to spend much time for scanning and editing the text. As a result, I have to lose most of the time. I am not able to spend time with my friends because I am not able to do things as they can do in case of studies. So I don't spend time with friends. In simple words, I can say that I don't have time to spend with my friends."

Some of them are unable to maintain their friendship and are not happy with their social life due to their impairments. It was also found that attitudes of these students, as well as that of their peer group, also affect their social relations and friendships. They believed that after knowing their condition and impairment, their friends will not encourage these students to go with them outside. They also underlined the importance of accessibility and creating a friendly environment within the campus which could improve their social life much better. The students noted:

"I did not find any problem with making new friends, but I could not enjoy my friendship or social life with them. the best example is I got invitation a couple of times from my friends for going out or spending time in shopping complexes' or canteens within the campus during the evenings. But my impairment doesn't permit me to go and spend time with them. It is uncomfortable for me to go for shopping to purchase my basic requirements because I cannot access all places with my tricycle that time I have to go inside without any support on mud road or floor."

It can be concluded from the narratives that majority of students were desirous to make new friends and maintain their relations and try to integrate socially in higher education institutions. However, it appears that some hindering factors, including their physical impairments, negative attitudes and lack of access and proper support for these students, create problems that are more significant and which affect their social experiences at higher education level. 


\section{Coping Strategies Used By Students with Disabilities in Managing Social and Higher Educational Experiences}

\section{Social Support}

The word social support has been defined by many theorists in different contexts in various ways. A definition given by Cobb (1976) consists of three components of social support: feeling valued or esteemed, feeling loved and belonging to a social network. In general, social support is one that is received from family, friends, and significant others in the individual's life, in order to deal with the effects of a stressful event. Support can be of three types: sharing the emotional burden by listening and accepting; actively participating in solving the problems and contributing additional resources (Ayalon, 1993).

In this study, respondents underlined the importance of support received from family members, friends, and the ones whom they were close to, could be seen as instrumental in helping the individual deal with the issues including both personal and education matters. Majority of them shared their experiences about how their parents helped and contributed to their success before and after coming to higher education. The respondents believed that they received unconditional support from their family members. For some of them, their parents expressed the importance of education and its success in their life. They always got encouragement, guidelines on how to succeed in education and other related aspects. Some of them also stated that when they failed to attain their targets, the family was there to help them move forward. The following narratives represent this group of respondents.

Kavitha stated that although she had multiple sources of support, her parents were an important source of support to her in daily life. "They have arranged a motor vehicle for me. Now I can go to class and come back to the hostel." Jagan also had support from his father. He stated, "My dad really helped me in each and every step of my academic career. He always supports my studies and gives me good guidance. Moreover, I got full freedom to choose my career of interest. He was like a friend and mentor. Deepthi had support from her parents in multiple ways. They admitted her in a six months computer course in Bengaluru. In addition, they also arranged a computer system with speech software's and scanner. Raghu noted "My parents always gave me moral support and encouragement. They always stand by me and push me to reach my targets." Shalini stated "I never thought I am a person with mobility impaired because my parents never allow me to think I cannot do anything. They always say that you can do whatever you dream of. They always say I should be independent and be of help to the other people in society."

Similarly, the respondents also stressed the importance of support from peer group in their education. Support from classmates/roommates/other peers has been a form of encouragement to pursue higher education, physical assistance with carrying books, pushing wheelchair/tri-cycle, reading and recording material at the time of exams and getting books from the library. For example, Deepika stated that whenever she is with her friends, all her problems will get solved. She doesn't think about the problems. They solve her problems and divert her from them. Rani, 


\section{Coping Strategies Used By Students with Disabilities in Managing Social and Higher Educational Experiences}

on the other hand, stated that her roommate is very helpful. She stated that when she approaches her for recording her material, she responds very positively. Similarly, Prathap indicated, " $M y$ friends always help me in pushing the wheelchair while coming and going from classroom to rest-rooms and vice-versa." Santhi also stated that her friends are very helpful. Whenever she requires material for scanning, she approaches her friends for help for getting material. Whenever their friends find material from either the library or their own classmates they will collect and give it to her.

From the above narratives, it can be concluded that students received various types of support which includes: guidance, emotional support, encouragement, arranging support services, assistance with problem solving, financial and transportation assistance. It was also noticed that majority of female respondents of the study consciously sought support from either parents or friends. Further, it is also obvious that those who received more social support from their parents and peer group were those with severe disabilities including persons with total visual impairment and wheel chair users or mobility impaired students. Thus, it can be interpreted that the importance of family and friends' social support in their lives is held very high and helped them to continue their studies successfully.

\section{Participation of Students with Disabilities in Extra-curricular activities}

Extra-curricular activities are pursued by students that fall outside the dominion of the normal university curriculum. A study conducted by Gilman (2001) indicates that students who participated in extra-curricular activities have a more successful development both socially and academically. Similarly, a study conducted by Dyson (2002) indicated that participation of students with disabilities in extra-curricular activities strengthens their integration. These students can acquire the basic skills necessary to participate partially in sports, student unions, and social events and other cultural programmes. These programmes give students with disabilities the opportunity to work with students without disabilities in a positive environment where everyone can actively contribute in one way or the other.

In the current study 81 of the respondents had not actively participated in extra-curricular/social activities in their universities. This study revealed that students who participated in extracurricular activities were only male students. Further, when participation of students was compared with the nature of impairment, it brought out that more number of students with orthopedically impairments participated when compared to students with visual impairments. Impairments, physical barriers, lack of social exposure, however, may hinder participation in some kinds of extra-curricular activities. Therefore, it can be concluded that participation in extra-curricular activities is not equally common for students across disability groups.

Further, the respondents of the study were asked "what kind of extracurricular activities have you been involved in other than academic activities since being enrolled in higher education? 


\section{Coping Strategies Used By Students with Disabilities in Managing Social and Higher Educational Experiences}

Students with disabilities require more energy to engage in activities outside the classroom. However, the respondents involved in many of the extra cultural activities including involvement in student organizations, activities, cultural events may had a significant influence of their social experience at higher education. They are actively involved in campus student organization and enjoyed their responsibilities. They noted:

"Being a person with disability (both legs affected,) I contested for the chairmanship for my hostel committee and took the responsibility of handling problems encountered by students in the hostel. I enjoyed being the hostel chairman because I got to work with so many people and I received many compliments from both the management and the students."

"I worked as a member in the student election commission. As a part of student election commission at the campus, I enjoyed and actively participated in the election commission. I took an important role as a member in election commission last year. It was a great experience."

"I am working as the President of Disability Cell committee on behalf of students with disability for this academic year. As a part of this committee, I actively participated in several meetings with the disability coordinator, and university employees' (Teaching and non-teaching persons with disabilities) and demanded our basic needs and rights."

"I had actively participated in extra-curricular activities. I also participated several times in national level chess competitions. Last year, I played and got the fifth position in chess championship."

A few of the respondents in this study were engaged in one or more extra-curricular activities. Several students joined as members of the committee so that they could be more involved with campus life and have opportunities that were more social. There were a majority of students with disabilities who did not participate in extra-curricular activities, but expressed an interest in participating in activities in the future. Further, it was also found that only 19 students who participated in extra-curricular activities were male students with disabilities. Many students expressed a concern about not being able to participate in extra-curricular activities. Overall, it is clear that those who participated were happy with their social life and the social experiences of learning in their universities helped them to make a good number of friends and actively participate in social and academic activities.

Similarly, a study conducted by Marsh and Kleitman (2002) revealed those students those who participated in extra-curricular activities were able to build and strengthen academic achievement. They also suggested that these activities should be well directed towards their development and should involve some physical and mental ability which is essential in their achievements. In this study, students' narratives showed that some of them were actively involved in social activities with support from friends. It was observed that due to the severity of their impairments, specially students with visual impairments, cannot enjoy social life with their friends, and it was also found that they didn't have much time to enjoy social activities due to 


\section{Coping Strategies Used By Students with Disabilities in Managing Social and Higher Educational Experiences}

their impairments since they need to spend extra time for studies, if they wanted to be independent or to achieve their goal in academics.

\section{Self - Advocacy}

Students with disabilities face various barriers in pursuing higher education. The term 'selfadvocacy' is defined in many ways, and institutions and researchers may disagree on the skills that should be included in self-advocacy programmes. A study conducted by Brinckerhoff (1994) suggests that the main components of self-advocacy are students knowing what she/he wants and to what she/he is legally entitled, and the ability of students with special needs to effectively achieve their goals. Effective self-advocacy requires that students understand their rights and responsibilities as students with disabilities in higher education institutions. In other words, they must assume responsibility for their educational experiences and for their impairments, learn about any available support services discussing their needs and issues with concerned people including university authorities, teachers and non-teaching staff. In this section, the researcher attempts to understand how far self-advocacy has contributed to a positive or negative social experience for students with disabilities within higher education institutions.

It is clear from Table 1 that students had more awareness about the Central and State government policies, and disabilities rights, as compared with existent disability cell/unit and disability coordinator at all the three universities. Thus, it can also be concluded from these findings that Central University students had significantly more awareness about the disability rights, existence of disability cell and coordinator than those in both the state universities. As we discussed in the methodology section, both Central and State University (a) had a disability cell and a coordinator, whereas in case of State University (b), it had neither a disability cell/unit nor a coordinator. Due to this reason, these students responded that either they didn't have or no idea about the existence of disability cell/unit, as well as coordinator, in their respective university. Similarly, it can be seen from Table that, visually impaired students had more awareness than those orthopedically impaired about the disability rights, existence of a disability cell and a coordinator in their universities. This is perhaps due to the fact that the provisions of support services for visually impaired students are more as compared with orthopedically impaired students in higher education institutions as per UGC rules. Thus, they should have an idea about concerned authorities and also have to frequently meet them in order to get support services including reader and scriber allowances, fees refund, arranging scribes and also for other technical assistive devices. Similarly, when we looked at the students awareness by gender, it is also noticed that majority of female students had significantly more awareness about the government schemes and scholarships, existence of disability cell and coordinator in their respective universities, as compared with male students. 


\section{Coping Strategies Used By Students with Disabilities in Managing Social and Higher Educational Experiences}

\section{Table 1: Students awareness by Nature of Impairment, Gender and Type of the University Disclosing their need with concerned Authority and Teachers}

Research studies have found that most of the higher education institutions have formulated disability policies and established disabled support services for students with disabilities. But results of the study shows that still there is a larger gap between policy and practice (Riddell, Tinklin and Wilson, 2005; and Howell's, 2005). It also shows that students with disabilities are struggling to receive ad hoc support in higher education institutions. In this context, the researcher was interested to find out whether students with disabilities informed the concerned authorities and the teachers about their needs and problems.

It can be seen from Table 2, that only 15 per cent of students informed the concerned authority and 16 per cent of them informed their course teacher about their problems and needs in their respective universities. Similarly, when we looked at students informing the concerned authorities by the nature of impairments, it was clear that more number of students with visually impairments informed the concerned authorities compared to orthopedically impaired students. Similarly, it was also found that only students with visual impairments informed the course teacher about their problems and needs at their universities. It can be concluded from the Table that significantly more visually impaired students informed the course teachers regarding their problems and needs in the classroom. This is perhaps due to the fact that needs of students with visual impairments are entirely different than these of orthopedically impaired students. Thus, they required more support services as compared to orthopedically impaired students in higher education institutions. They have unique educational needs. In order to meet their unique needs, these students must have specialised equipment and technology and services, books and materials in Braille to assure equal access to the curriculum and to enable them to participate equally along with their peer groups in higher education. Thus these students have to meet the concerned higher authorities, teachers frequently and discuss their requirements including study material, extra time during exams time, reader and scribe allowances, fees refund, arranging scribes and also for technical assistive devices. Similarly, when students informed the concerned authorities and teachers, it was found that female students were more informed about their needs compared to their male counterparts.

Finally, it is clear from Table 2 that Central University students were significantly more in informing the concerned authorities and teachers about their problems and needs than State University students. It also shows that none of the students from State University (b) informed the concerned authority about their needs and problems at their university. The fact is that students from State University (b) neither had a disability cell/unit nor disability coordinator to discuss their issues at their university. Therefore, it can be concluded that students who had a disability cell/unit and a coordinator, have an opportunity to discuss their needs in order to get support services to enable them to pursue their studies successfully. It can also be concluded that 


\section{Coping Strategies Used By Students with Disabilities in Managing Social and Higher Educational Experiences}

more number of students from Central University informed the concerned authorities and teachers about their special needs and problems. Similarly, it is obvious that students with visual impairments were more in frequent contact with the administrative authorities and teachers to discuss their unique needs and most of them were female students. Similarly, research study conducted by Braithwaite (1991) also points out that students disclosed their disabilities to the teachers in order to receive necessary facilities in the classroom such as getting extra time during examination, teaching aids, and learning resources. But all these factors are based on the assumptions that the disclosure is purely voluntary in nature for them.

\section{CONCLUSION}

The data from this study provided a greater understanding has been gained regarding coping strategies adopted by them to manage their higher education experiences. Similarly, those students who informed/or disclosed their disabilities and special needs to their teachers and higher authorities, benefited more by getting their requirements fulfilled such as reservations, rights and special provisions, support services, extra time during exams time, reader and scribe allowances, and also various support services. The important point is that students who actively participated in various extra-curricular activities developed higher social skills as well as achieved more success in academics than those who did not. Their active participation in sports, student unions, social events and other cultural programmes has significant by influenced their social experience in higher education and strengthened their integration. Overall, the respondents in this study faced various problems in pursuit and participation in higher education. However, they received support from various sources such as university, family, friends, teachers and some of them were persistent in their special needs in order to meet actively participate and achieve their goals.

\section{REFERENCES}

Adrianne L., Johson M.S., NCC, LAC 2006. Students with Disabilities in Post Secondary Education: Barriers to Success and Implications for professionals, VISTAS, 2006

Ayalon, O. 1993. Posttraumatic stress recovery of terrorist survivors. In J. P. Wilson and B. Raphael (Eds), International Handbook of traumatic stress syndromes (pp. 855866). New York: Plenum Press.

Barron, K. 2001. Autonomy in everyday life, for whom? Disability and Society, Vol. 16, No. 3, pp: $431-447$.

Braithwaite, 1991. Just how much did that wheel chair cost? Management of privacy boundaries by persons with disabilities. In Brak, L.,(2010). Accommodation strategies of college students with disabilities. The Qualitative Report, Vol 15, No. 2.

Chanana, Karuna 1993. "Accessing Higher Education: The Dilemma of Schooling Women, Minorities, Scheduled Castes and Scheduled Tribes in Contemporary India." Higher Education, 26, pp: 69-92.

Cosden. A and McNamara, Joanne 1997. Self-Concept and Perceived Social Support among College Students with and without Learning Disabilities, Learning Disability Quarterly, Vol. 20, No. 1 (Winter, 1997), pp. 2-12. 


\section{Coping Strategies Used By Students with Disabilities in Managing Social and Higher Educational Experiences}

Dyson, D. 2002. Utilzing Available Resource at the Local Level. In Adeyemo, S 2010. The relationship between students participation in school based extra-curricular activities and their achievement in physics. International Journal of Science and Techonology Education Research. Vol. 1 (6), pp.111-117.

Frith H, Rapley M 1990. From Acquaintance to Friendship: issues for people with Learning Disabilities. Kidderminster: BIMH Publications

Heiman, T. 2006. Social Support Networks, Stress, Sense of Coherence and Academic Success of University Students with Learning Disabilities. Social Psychological of Education, Vol. 9, pp: 461-478

Hoy.C, Gregg.N, Wisenbaker.J, Manglitz.E, King.M, Moreland.C 1997. Depression and Anxiety in Two Groups of Adults with Learning Disabilities, Learning Disability Quarterly, Vol. 20, No. 4 (Autumn, 1997), pp. 280-291

Howell, 2005. 'Higher Education Monitor', South African Higher Education response to Students with Disabilities, Equity of Access and Opportunity, University of the Western Cape', Council of Higher Education, No.3, September, 2005.

IECYD, 2005. Action Plan for Inclusive Education of Children and Youth with Disabilities, 2005

Jacklin. A, Robin. C, and Harris. A 2007. Improving the Experiences of Disabled Students in Higher Education, The Higher Education Academy, University of Sussex, 2007.

Marsh HW, Kleitman S 2002. Extracurricular activities: The good, the bad, and the nonlinear. Harvard Educational Review, 72,464-512, NCPEDP Survey (2004)

Nunkoosing. K. and John. M 1997. Friendships, relationships and the management of rejection and loneliness by people with learning disabilities, Journal of Intellectual Disabilities, 1997; $1 ; 10$

Riddell, S., T. Tinklin and A. Wilson 2005. New Labour, social justice and disabled students in higher education. British Educational Research Journal, Vol. 31, No. 5: 623-43.

Yeo, R., \& Moore, K. 2003. Including disabled people in poverty reduction work: "Nothing about us, without us". World Development, 31 (3), 571-590. 
Coping Strategies Used By Students with Disabilities in Managing Social and Higher Educational Experiences

Table 1: Students awareness by Nature of Impairment, Gender and Type of the University

\begin{tabular}{|c|c|c|c|c|c|c|c|c|c|c|c|c|c|c|c|c|c|}
\hline \multirow{3}{*}{\multicolumn{2}{|c|}{ Variables }} & \multicolumn{16}{|c|}{ Students awareness } \\
\hline & & \multicolumn{3}{|c|}{$\begin{array}{c}\text { Central govt } \\
\text { schemes }\end{array}$} & \multirow[t]{2}{*}{$\begin{array}{c}\text { Tot } \\
\text { al }\end{array}$} & \multicolumn{3}{|c|}{$\begin{array}{c}\text { Disability } \\
\text { Rights }\end{array}$} & \multirow[t]{2}{*}{$\begin{array}{c}\text { Tot } \\
\text { al }\end{array}$} & \multicolumn{3}{|c|}{$\begin{array}{l}\text { Disability } \\
\text { Cell/Unit }\end{array}$} & \multirow[t]{2}{*}{$\begin{array}{c}\text { Tot } \\
\text { al }\end{array}$} & \multicolumn{3}{|c|}{ Coordinator } & \multirow[t]{2}{*}{$\begin{array}{l}\text { Tot } \\
\text { al }\end{array}$} \\
\hline & & $\begin{array}{l}Y \\
\text { es } \\
(5 \\
7)\end{array}$ & $\begin{array}{l}\mathrm{N} \\
\mathrm{O} \\
(4 \\
3)\end{array}$ & $\begin{array}{l}\mathrm{N} \\
\mathrm{o} \\
\mathrm{id} \\
\mathrm{ea}\end{array}$ & & $\begin{array}{l}\text { Y } \\
\text { es } \\
(7 \\
3)\end{array}$ & $\begin{array}{l}\mathrm{N} \\
\mathrm{o} \\
(2 \\
7)\end{array}$ & $\begin{array}{c}\text { o } \\
\text { id } \\
\text { ea }\end{array}$ & & $\begin{array}{l}\mathrm{Y} \\
\text { es } \\
(3 \\
1)\end{array}$ & $\begin{array}{l}\mathrm{N} \\
\mathrm{O} \\
(4 \\
2)\end{array}$ & $\begin{array}{c}\mathrm{N} \\
\mathrm{o} \\
\mathrm{id} \\
\mathrm{ea} \\
(2 \\
7)\end{array}$ & & $\begin{array}{l}\text { Y } \\
\text { es } \\
(4 \\
5)\end{array}$ & $\begin{array}{l}\mathrm{N} \\
\mathrm{O} \\
(4 \\
9)\end{array}$ & $\begin{array}{c}\mathrm{N} \\
\mathrm{o} \\
\mathrm{id} \\
\mathrm{ea} \\
(6 \\
)\end{array}$ & \\
\hline \multirow{6}{*}{$\begin{array}{c}\text { Impair } \\
\text { ment }\end{array}$} & $\mathrm{O} \mathrm{I}$ & 42 & 30 & - & 72 & 50 & 22 & - & 72 & 18 & 35 & 19 & 72 & 30 & 37 & 5 & 72 \\
\hline & & $(5$ & $(4$ & & $(10$ & $(7$ & $(3$ & & $(10$ & $(2$ & $(4$ & $(2$ & $(10$ & $(4$ & $(5$ & $(7$ & $(10$ \\
\hline & & 8) & 2) & & 0) & 0) & 0) & & 0) & 5) & 9) & 6) & 0) & 2) & 1) & ) & 0) \\
\hline & V I & 15 & 13 & - & 28 & 23 & 5 & - & 28 & 13 & 7 & 8 & 28 & 15 & 12 & 1 & 28 \\
\hline & & $(5$ & $(4$ & & $(10$ & $(8$ & $(1$ & & $(10$ & (4 & $(2$ & $(2$ & $(10$ & $(5$ & $(4$ & $(3$ & $(10$ \\
\hline & & 4) & 6) & & 0) & 2) & 8) & & 0) & 6) & 5) & 9) & 0) & 4) & 3) & ) & 0) \\
\hline \multirow[t]{6}{*}{ Gender } & Mal & 37 & 29 & - & 66 & 49 & 17 & - & 66 & 14 & 30 & 22 & 66 & 24 & 38 & 4 & 66 \\
\hline & $\mathrm{e}$ & $(5$ & (4 & & $(10$ & (7 & $(2$ & & $(10$ & (2 & (4 & (3 & $(10$ & (3 & $(5$ & $(6$ & $(10$ \\
\hline & & 6) & 4) & & 0) & 4) & 6) & & 0) & 1) & 6) & 3) & 0) & 6) & 8) & ) & 0) \\
\hline & Fem & 20 & 14 & - & 34 & 24 & 10 & - & 34 & 17 & 12 & 5 & 34 & 21 & 11 & 2 & 34 \\
\hline & ale & $(5$ & (4 & & $(10$ & (7 & $(2$ & & $(10$ & $(5$ & (3 & (1 & $(10$ & $(6$ & $(3$ & $(6$ & $(10$ \\
\hline & & 8) & 2) & & 0) & 1) & 9) & & 0) & 0) & 5) & 5) & 0) & 2) & 2) & ) & 0) \\
\hline \multirow{9}{*}{$\begin{array}{c}\text { Type } \\
\text { of the } \\
\text { Univer } \\
\text { sity }\end{array}$} & $\mathrm{CU}$ & 24 & 24 & - & 48 & 36 & 12 & - & 48 & 24 & 10 & 14 & 48 & 30 & 18 & - & 48 \\
\hline & & $(5$ & $(5$ & & $(10$ & (7 & $(2$ & & $(10$ & $(5$ & $(2$ & $(2$ & (10 & $(6$ & $(3$ & & $(10$ \\
\hline & & 0) & 0) & & 0) & 5) & 5) & & 0) & 0) & 1) & 9) & 0) & 3) & 7) & & 0) \\
\hline & SU & 14 & 12 & - & 26 & 17 & 9 & - & 26 & 7 & 14 & 5 & 26 & 15 & 10 & 1 & 26 \\
\hline & (a) & $(5$ & (4 & & $(10$ & $(6$ & $(3$ & & $(10$ & (2 & (5 & (1 & (10 & $(5$ & (3 & $(4$ & (10 \\
\hline & & 4) & 6) & & 0) & 5) & 5) & & 0) & 7) & 4) & 9) & 0) & 8) & 8) & ) & 0) \\
\hline & SU & 19 & 7 & - & 26 & 20 & 6 & - & 26 & - & 18 & 8 & 26 & - & 21 & 5 & 26 \\
\hline & (b) & (7 & $(2$ & & (10 & (7 & (3 & & (10 & & (6 & (3 & (10 & & (8 & (1 & (10 \\
\hline & & 3) & 7) & & 0) & 7) & 3) & & 0) & & 9) & 1) & 0) & & 1) & 9) & 0) \\
\hline
\end{tabular}

(Note: The figures in the parenthesis are percentages) 
Coping Strategies Used By Students with Disabilities in Managing Social and Higher Educational Experiences

Table: 2 Percentage of Students who informed the concerned Authority and Teachers' by Impairment, Gender \& University

\begin{tabular}{|c|c|c|c|c|c|c|c|}
\hline \multirow{2}{*}{\multicolumn{2}{|c|}{ Variables }} & \multicolumn{2}{|c|}{$\begin{array}{c}\text { Informing course } \\
\text { Authority }\end{array}$} & \multirow{2}{*}{$\begin{array}{l}\text { Total } \\
(100)\end{array}$} & \multicolumn{2}{|c|}{$\begin{array}{c}\text { Informing course } \\
\text { Teacher }\end{array}$} & \multirow{2}{*}{$\begin{array}{l}\text { Total } \\
(100)\end{array}$} \\
\hline & & $\begin{array}{l}\text { Yes } \\
(15)\end{array}$ & $\begin{array}{l}\text { No } \\
(85)\end{array}$ & & $\begin{array}{l}\text { Yes } \\
(16)\end{array}$ & $\begin{array}{l}\text { No } \\
(84)\end{array}$ & \\
\hline \multirow[t]{2}{*}{$\begin{array}{c}\text { Nature of } \\
\text { Impairment }\end{array}$} & $\begin{array}{l}\text { Orthopedic } \\
\text { impairments }\end{array}$ & $\begin{array}{c}4 \\
(6)\end{array}$ & $\begin{array}{c}68 \\
(94)\end{array}$ & $\begin{array}{c}72 \\
(100)\end{array}$ & - & $\begin{array}{c}72 \\
(100)\end{array}$ & $\begin{array}{c}72 \\
(100)\end{array}$ \\
\hline & $\begin{array}{c}\text { Visual } \\
\text { impairments }\end{array}$ & $\begin{array}{c}11 \\
(39)\end{array}$ & $\begin{array}{c}17 \\
(61)\end{array}$ & $\begin{array}{c}28 \\
(100)\end{array}$ & $\begin{array}{r}16 \\
(57)\end{array}$ & $\begin{array}{r}12 \\
(43)\end{array}$ & $\begin{array}{c}28 \\
(100)\end{array}$ \\
\hline \multirow[t]{2}{*}{ Gender } & Male & $\begin{array}{c}9 \\
(14)\end{array}$ & $\begin{array}{c}57 \\
(86)\end{array}$ & $\begin{array}{c}66 \\
(100)\end{array}$ & $\begin{array}{r}10 \\
(15)\end{array}$ & $\begin{array}{r}56 \\
(85)\end{array}$ & $\begin{array}{c}66 \\
(100)\end{array}$ \\
\hline & Female & $\begin{array}{c}6 \\
(18)\end{array}$ & $\begin{array}{c}28 \\
(82)\end{array}$ & $\begin{array}{c}34 \\
(100)\end{array}$ & $\begin{array}{c}6 \\
(18)\end{array}$ & $\begin{array}{c}28 \\
(82)\end{array}$ & $\begin{array}{c}34 \\
(100)\end{array}$ \\
\hline \multirow[t]{3}{*}{$\begin{array}{l}\text { Type of the } \\
\text { University }\end{array}$} & $\begin{array}{c}\text { Central } \\
\text { University }\end{array}$ & $\begin{array}{l}14 \\
(29)\end{array}$ & $\begin{array}{c}34 \\
(71)\end{array}$ & $\begin{array}{c}48 \\
(100)\end{array}$ & $\begin{array}{r}12 \\
(25)\end{array}$ & $\begin{array}{c}36 \\
(75)\end{array}$ & $\begin{array}{c}48 \\
(100)\end{array}$ \\
\hline & $\begin{array}{c}\text { State } \\
\text { University } \\
\text { (a) }\end{array}$ & $\begin{array}{c}1 \\
(4)\end{array}$ & $\begin{array}{c}25 \\
(96)\end{array}$ & $\begin{array}{c}26 \\
(100)\end{array}$ & $\begin{array}{c}1 \\
(4)\end{array}$ & $\begin{array}{c}25 \\
(96)\end{array}$ & $\begin{array}{c}26 \\
(100)\end{array}$ \\
\hline & $\begin{array}{c}\text { State } \\
\text { University } \\
\text { (b) }\end{array}$ & - & $\begin{array}{c}26 \\
(100)\end{array}$ & $\begin{array}{c}26 \\
(100)\end{array}$ & $\begin{array}{c}3 \\
(12)\end{array}$ & $\begin{array}{c}22 \\
(88)\end{array}$ & $\begin{array}{c}26 \\
(100)\end{array}$ \\
\hline
\end{tabular}

(Note: The figures in the parenthesis are percentages) 